\title{
The Impact of Demonstration Learning on Pupils Understanding of Preparation of Salts
}

\author{
Mubanga Lupupa Mubanga Aubriel, \\ School of Natural Sciences, Copperbelt University, PO box 21692, Kitwe, Zambia
}

\begin{abstract}
The study examined the impact of Demonstration learning on the pupils' understanding of the preparation of salts. The study adopted an experimental design involving two groups with members who were randomly assigned. The population of the study was grade eleven (11) pupils at Chingola Secondary school. The site of the study was a grade eleven classroom. Data were collected using pre and post-tests. The analysis of data was done using descriptive statistics and independent $t$ test. The results of the study were that Demonstration method had significant impact on the pupils' understanding of the preparation of salts.
\end{abstract}

Keywords: Demonstration method, Salts

DOI: $10.7176 / \mathrm{JEP} / 11-3-13$

Publication date: January $31^{\text {st }} 2020$

\section{Introduction}

The success of a lesson depends on what kind of a teaching method a teacher is using to teach learners. Demonstration learning has been considered to be one of the most effective teaching methods. The method of teaching by demonstration is based on the simple, yet sound principle that we learn by doing. An individual learns to write by writing, to weld by welding, and to fly an aircraft by actually performing flight maneuvers. Although this method best suits teaching skills requiring the use of tools, machines, and equipment, it can also be used in teaching scientific processes because they both involve steps on achieving the desired results (Bruce, 2010). Demonstration strategy focuses to achieve psychomotor and cognitive objectives.

This study focused on how to implement demonstration method of teaching effectively in order to enhance the learning and teaching of chemistry in secondary schools. Preparation of salts was used as a test case during this study. A salt is a compound formed when the hydrogen ions in an acid are replaced by metal ions or ammonium ions. Salts are prepared by reacting an acid with a metal or a base such as carbonates, hydroxides or oxides. In order to help the pupils understand preparation of salts, they need to be involved in demonstrating how the acid reacts with a metal or a base (Fred, 2010). Preparation of salts is a topic taught at grade 11 level according to Zambia secondary school Chemistry syllabus.

\section{Statement of the problem}

Salt is something which part of daily experiences of school pupils. However, the process of its preparation is an abstract topic, far from the pupils daily experience. As pupils cannot see and differentiate the solubility salts, materials required and how to obtain pure crystals from the solution, it is difficult for them to understand the concepts involved in the topic of salt preparation. As a result, there is great potential for the learners to face challenges in the learning process (Enerst, 2010). The temptation mainly is for the teacher to force learners to memorize subject matter in chemistry merely to be able to recall this information in the examination. However, there is no real value in learning scientific knowledge through memorization. Until and unless a leaner practices or undergoes hands on learning in the science classroom, gaining conceptual understanding into science concepts remains a utopian dream for majority of students (Derek, 2007). To address this problem, this study investigated the impact of Demonstration method on pupils understanding of preparation of salts.

\section{Literature Review}

The literature reviews various studies conducted in related science subjects and lessons where demonstration method has been used. In teaching through demonstrations, concepts and processes are observed directly. Demonstrations often occur when students have a hard time connecting theories to actual practice or when students are unable to understand application of theories, (Mckee, 2007). Giridharan and Raju (2016, p 175) define demonstration as, "a method of teaching concepts, principles of real things by combining with handling or manipulation of real things, materials or equipment." Looking at the definition of demonstration learning given above, it resonates well with its use in the teaching and learning of preparation of salts. The method involves the teaching of concepts and the manipulation of real things, which in this case can referred to salt.

Basheer, Hugerat, Kortam and Hofstein (2017) conducted a study on the effectiveness of teachers' use of demonstrations for enhancing students' understanding of and attitudes to learning the oxidation-reduction. The study endeavored to compare an experimental group with the control group, which was not exposed to demonstration method. It was found that the experimental group's achievement and understanding of the subject 
matter were significant, better than those of the control group were. From that study, it was concluded that demonstration, as a method, could be used to enhance effective understanding of certain chemistry concepts as well as increasing pupils' motivation and interest to learn chemistry. Since this study concentrated on oxidationreduction and electrolysis, it is imperative to use the same method on the preparation of salts. It is not clear whether the same results could be realized when used on the preparation of salts to grade eleven pupils.

Also, a study done by Giridharan and Raju (2016) investigated the impact of teaching strategies and teacher effect on academic achievement in engineering education where two strategies namely; demonstration and lecture strategies were used. Using experimental research design, teaching strategies and teacher effect were independent variables while academic achievement was a dependent variable. Two way ANOVA showed that there was significant effects of teacher strategies and teacher effect. The study indicated and concluded that demonstration method was found to be significantly better than lecture method in producing the required academic achievement. This study investigated demonstration method and had implications for improving the quality of engineering education; however, it is not clear whether this strategy can produce positive results concerning pupils' understanding of preparation of salts in chemistry lesson.

In a study that investigated the effects of demonstration method of teaching on students' achievement in agricultural science, Ekeyi (2013) employed a quasi-experimental research design. The findings were that demonstration method had significant effect on the student's achievement than those taught using lecture method. Despite recording the achievements in the teaching of agriculture science, the same cannot be said with the teaching of chemistry in the preparation of salts in the laboratory, the gap that this study sought to bridge.

Ramadhan and Surya (2017) carried out an action research to increase students' ability in learning mathematics in operating multiple numbers using concrete objects by implementing demonstration method. The study revealed that learning outcomes increased at second and third cycles having recorded the completion percentage value of 72.5 and 86.67 respectively after seeing the learning process through observation and reflection on the first cycle. It was, therefore, concluded that demonstration method increased students' ability in operating multiple numbers using concreate objects, hence, increasing the students' ability in learning mathematics. This study provoked the need to use demonstration method to foster pupils' understanding of preparation of salt in chemistry. However, its impact on pupils' understanding was not ascertained, hence the need for the current study.

\section{Method}

\subsection{Research Design}

This study used the experimental design. Experimental research is the most appropriate way for determining causal relationships between variables.

\subsection{Research site}

The research was conducted at Chingola secondary school; this school is located in Chingola on the Copperbelt province of Zambia. The school offer lessons from grade eight up to twelve. The school has a total of 51 classes that is: 5 grade eight classes, 5 grade nine classes, 5 grade ten classes, 5 grade eleven classes and 5 grade twelve classes.

\subsection{Population}

The population for this study comprised all grade eleven pupils. The total population of these grade eleven classes was 345 pupils.

\subsection{Procedure}

At total sample size of 52 grade eleven pupils were selected from one regular class using simple random sampling. It is from this sample that two groups (the control and the experiment) were randomly formed. The subjects were assigned randomly to the experimental and control groups. The experimental group was subjected to treatment while the control was not.

\subsection{Data collection}

Data were collected using pre and posttests. The pretest was meant to identify the problem to be addressed. It allows the researcher to identify potential problems which they are trying to solve. Therefore, the purpose of the pre-test was to find out if learners had enough knowledge that would help them understand the topic being taught. The researcher prepared a ten-item test which was given to both experimental group and the control group. The posttest was administered to both experimental group and control group after the treatment was done on the experimental group.

4.6 Data Analysis

Data were analyzed using descriptive statistics and t-test. Whereas the performance of pupils was analyzed using 
descriptive statistics, the variance between the pre and posttests was done using independent sample t-test.

5. Results

Table 1: Descriptive Statistics for the Control Group and Experimental Pretest Results

\begin{tabular}{lll}
\hline Statistic & Experimental Group Pretest & Control Group Pretest \\
\hline N & 26 & 26 \\
Mean & 30.46 & 32.38 \\
Median & 30.00 & 30.00 \\
Mode & 20 & 20 \\
Std. Deviation & 10.168 & 13.369 \\
Range & 35 & 50 \\
Minimum & 20 & 20 \\
Maximum & 55 & 70 \\
\hline
\end{tabular}

Table labove shows that the control group had a greater mean than the experimental group by $1.92 \%$. Both groups had same median and same mode of $20 \%$. The maximum score for the control group was greater than that of the experimental group by 15\%. Range score for the control group was higher than that of the experimental group by $15 \%$.The standard deviation for the control group was higher than that of the experimental group by $3.201 \%$.

Table 2: Independent sample t test for the pretest means

\begin{tabular}{llllllll}
\hline Variance & $\mathbf{t}$ & $\mathbf{D f}$ & $\begin{array}{l}\text { Sig. } \\
\text { tailed) }\end{array}$ & $\begin{array}{l}\text { Mean } \\
\text { Difference }\end{array}$ & $\begin{array}{l}\text { Std. } \\
\text { Difference }\end{array}$ & $\begin{array}{l}\text { Error } \\
\text { C5\% } \\
\text { Confidence } \\
\text { Interval }\end{array}$ \\
\hline $\begin{array}{l}\text { Equal variances } \\
\text { assumed }\end{array}$ & -.584 & 50 & .562 & -1.923 & 3.294 & lower & Upper \\
$\begin{array}{l}\text { Equal variances } \\
\text { not assumed }\end{array}$ & -.584 & 46.671 & .562 & -1.923 & 3.294 & -8.539 & 4.693 \\
\hline
\end{tabular}

According to the table above, the level of significance is 0.562 , since the significance values greater than the alpha value $(\alpha=0.05)$ then there is no significant difference between these two means. Thus, the null hypothesis is accepted to be true. This shows that the two groups were significantly equal at the start of the study.

Table 3: Descriptive statistics of the posttest for Control and Experimental group

\begin{tabular}{lcc}
\hline Statistics & Experimental Group Posttest Results & Control Group Posttest Results \\
\hline $\mathrm{N}$ & 26 & 26 \\
Mean & 72.12 & 51.54 \\
Median & 75.00 & 50.00 \\
Mode & 75 & 50 \\
Std. Deviation & 11.850 & 11.293 \\
Range & 40 & 45 \\
Minimum & 50 & 30 \\
Maximum & 90 & 75 \\
\hline
\end{tabular}

According to table 3 above the experimental group had a higher mean than the control group by $20.58 \%$.Control had the median of $50.00 \%$ while the experimental group had a median of $75 \%$. The control group had a smaller maximum scores compared to the maximum score which the experimental group had, the difference was $15 \%$.

Table 4: Independent sample t test for the post test results

\begin{tabular}{llllllll}
\multicolumn{1}{c}{ Variance } & T & df & $\begin{array}{l}\text { Sig. } \\
\text { tailed) }\end{array}$ & $\begin{array}{l}\text { Mean } \\
\text { Difference }\end{array}$ & $\begin{array}{l}\text { Std. } \\
\text { Difference }\end{array}$ & $\begin{array}{l}\text { Error } \\
\text { Confidence } \\
\text { Interval }\end{array}$ \\
\hline $\begin{array}{l}\text { Equal variances } \\
\text { assumed }\end{array}$ & 6.410 & 50 & .000 & 20.577 & 3.210 & Lower & Upper \\
$\begin{array}{l}\text { Equal variances } \\
\text { not assumed }\end{array}$ & 6.410 & 49.885 & .000 & 20.577 & 3.210 & 14.129 & 27.025 \\
\hline
\end{tabular}

According to table 4 above, the $p$ value $(0.00)$ is less than the alpha value $(0.05)$. This means that the difference between means of the pre and posttests was significant. Therefore, the null hypothesis is rejected and the Alternative (research) is adopted (accepted) in this study. It can be concluded that demonstration learning has a positive impact on grade eleven pupils understanding of preparation of salts.

6. Discussion of the findingsThe study examined that impact of demonstration on pupils' understanding of the preparation of salts in chemistry. The study showed that the mean difference between the pre and posttests was 
significant as the $\mathrm{p}$ value (0.00) was less than the alpha value $(0.05)$. This implied that demonstrated method had a significant impact on pupils' understanding of the preparation of salts. The result is consistent Ekeyi (2013) who asserted that demonstration method had significant effect on the student's achievement than those taught using lecture method. Similarly, Giridharan and Raju (2016) concluded that demonstration method was significantly better than lecture method in producing the required academic achievement.

\section{Conclusion}

The study sought to investigate the impact of the Demonstration method on the pupils' understanding of the preparation of salts. The pretest result analysis showed that the mean difference for the control and the experimental groups was not significant; meaning that there was no group which was better than the other at the onset of the study. The post-test analysis, however, showed that showed significant difference between the means of the control and experimental groups. The two means (control and experimental) were statistically significant. Form this it concluded that teaching the topic preparation of salts improved the understanding of the pupil regarding to this topic. The outcome of this study is consistent with the theory that effective teaching of science should be based on hands-on activities.

\section{References}

Basheer, A., Hugerat, M., Kortam, N., Hofstein, A. (2017). The Effectiveness of Teachers' Use of Demonstrations for Enhancing Students' Understanding of and Attitudes to Learning the Oxidation-Reduction Concept. Eurasia Journal of Mathematics, Science and Technology Education, 13(3), 555-570.

Derek C (2007). Students' attitudes toward chemistry lessons: the interaction effect between grade level and gender, Res. Edu, (5):1573-1898

Ekeyi, D., N. (2013). Effect of Demonstration Method of Teaching on Students' Achievement in Agricultural Science. Anyigba: Kogi State University.

Ernest, F.O. (2010). Relative effects of programmed instruction and demonstration method of students' academic performance in science. College study Journal, June 2009.

Fred, G.A. (2010). A comparative effectiveness of the lecture- demonstration and individual laboratory methods. The Journal of Educational Research, 1 \& 3(5), 355-365.

Giridharan, K., \& Raju, R. (2016). Impact of Teaching Strategies: Demonstration and Lecture Strategies and Impact of Teacher Effect on Academic Achievement in Engineering Education. International Journal of Education Science, 14(3): 174-186

Holstermann, N., Grube, D., \& Bögeholz, S. (2010). Hands-on Activities and Their Influence on Students' Interest. Research in Science Education 40: 743.

Millar, R. (2004). The role of practical work in the teaching and learning of science: Paper prepared for the Committee: High School Science Laboratories: Role and Vision, National Academy of Sciences. Washington, DC: University of York. 